\author{
Aleksandra Sikorska-Krystek \\ Domaine Slavistique, Université de Fribourg \\ Jędrzej Krystek \\ Instytut Filologii Polskiej, Uniwersytet im. Adama Mickiewicza w Poznaniu

\section{Pieśń ku niebiosom. Echa chopinowskie w twórczości Artura Oppmana}

\author{
Ach, ten Szopen! Boże! Boże! \\ Ach, ten Szopen i Ujejski! \\ Wjakiż oni wioda duszę \\ Świat tęczowy, czarodziejski! \\ Przy tych tonach, przy tej pieśni \\ Niech przemarzę zycie cate! \\ Łzy się prześnia, ból się prześni \\ I serdeczny żal... \\ I anielskie skrzydta biate \\ Wzwyż poniosa mnie... w btękity, \\ Tam, pod gwiazdy, tam - na szczyty! \\ $W$ nieskończoność... $w$ dal... \\ Te walczyki, te mazurki, \\ I preludia, i te scherza - \\ Ptyna, ptyna z fortepianu, \\ Ptyna, ptyna wprost do serca! \\ Takie rzewne, takie śpiewne, \\ Takie tęskne i anielskie, \\ Jak piosenki jakie sielskie, \\ Jak modlitwy szmer!...
}

Artur Oppman, Marsz Szopena

Andrzej Hejmej w tekście Chopin i jego muzyka w literaturze, poświęconym lirycznym XIX-wiecznym odpowiedziom na twórczość polskiego kompozytora, stwierdza, że ówczesne „próby literackie 
[...] tworzą swoiste przekonanie o kongenialności poetyckiego przekładu muzyki” [Hejmej 2020]. Jako przykłady „typowych fabularyzacji Chopinowskiej muzyki” badacz wymienia m.in. Tęsknotę. Mazurek op. 6. nr 4 Włodzimierza Wolskiego, Trzpiotkę Michała Bałuckiego, Chopin. Preludium nr 15 Lucjana Rydla, a także „poetyckie preludia Artura Oppmana” [Hejmej 2020]. Szczególnie ostatni $\mathrm{z}$ wymienionych autorów $\mathrm{z}$ kilku powodów zasługuje na uwagę. Jeden z ulubionych poetów Jana Lechonia do muzyki polskiego mistrza powracal w swej poezji wielokrotnie, opatrując tytuly utworów nazwami wielu muzycznych form, które tworzył kompozytor.

W 1893 roku, a zatem niemal 11 lat od literackiego debiutu, Oppman opublikował w warszawskiej księgarni Paprockiego i Spółki drugi tomik poezji - Pieśni. Na zawartość zbioru, którego tytuł otwierał szereg konotacji z muzyką, składały się cykle: $Z$ serca iz ducha, Bliskiej... dalekiej, Z motywów Szopena, Szkice z zautków, Piosnki pod muzykę, Średniowieczne echa, Na skrzypkach, Z dziejów świata, Mozaika. Obszerny tom poetycki, obejmujący ponad 100 utworów, w przeciwieństwie do późniejszej twórczości poety nie zdobył uznania krytyków. Charakteryzując zawartość Pieśni, Stanisław Kozłowski pisal, że możemy w tym tomie znaleźć „kołysanki, walce, mazurki układane pod muzykę Chopina” [Kozłowski 1893]. To właśnie temu cyklowi przeciwstawiał pozostałą zawartość tomiku: „W kołysankach wszędzie dźwięczy nuta szczerości, której nie odnajdujemy ani w beznamiętnych skargach miłosnych, ani w mdłym pesymizmie autora" [Kozłowski 1893]. Stwierdzał też jednoznacznie, że Oppman „lepiej nuci, niż maluje” [Kozłowski 1893], podkreślając tym samym muzyczne inklinacje twórczości młodego poety.

Nim Oppman włączył cykl Z motywów Chopina do Pieśni, opublikował niektóre należące do niego utwory na łamach prasy. Kompozycja Preludium Chopina, inc. ${ }^{* * *}$ [Chopinowska piosnka płynie... ] ujrzała światło dzienne w „Echu Muzycznym, Teatralnym i Artystycznym" w 1890 roku [Or-Ot 1890$]$. Walc, inc. ${ }^{* * *}$ [Oplotła nas marzeń tęczowa sieć], nim został włączony do Pieśni, ukazał się w krakowskiej „Myśli” [Or-Ot 1892: 1]. Pięć lat później w krakowskim „Życiu” zaprezentowano też utwór $Z$ motywów Chopina, inc. $^{* * *}[$ O graj... Jak szumi smętny gaj...][Oppman 1898]. Decyzje 
wydawnicze podejmowane przez Oppmana na przestrzeni lat sugerują, że poeta darzył omawiany cykl szczególną estymą, bowiem należące do niego utworu włączał także do późniejszych tomików swoich wierszy. I tak w Wyborze poezji z 1900 roku zamieścił: Deszcz. Preludium, inc. ${ }^{* * *}[$ Deszcz za oknem mży...], Pieśń Szopena, inc. ${ }^{* * *}\left[\right.$ Spod twych rączek...], Pożegnanie. Walc, ${ }^{* * *}[$ Och, opleć mnie dłonią, och, opleć białą...], Srebrne dzwonki. Kotysanka, inc. ***[Dzwoń, dzwoneczku, dzwoń srebrny...], W pótśnie. Scherzo, *** [Na modrym, na niebie...] a w nowym wydaniu, uzupełnionym i poprawionym, z roku 1908 cykl chopinowski uzyskał nieco inną odsłonę względem wcześniejszych publikacji. Po pierwsze, zmieniono tytuł zbioru na Szopenowskie pieśni. Po drugie, poszerzono poetycki cykl o nowe utwory. Tym razem inicjował go wiersz Szopen, inc. ${ }^{* *}$ [Przylgnął uchem do ziemi, posłyszał jej łkanie...], po czym następowały: Pieśń Szopena, Srebrne dzwonki. Kolysanka, Marzenie. Preludium, Deszcz. Preludium, Pożegnanie. Walc, Stach. Mazurek, $W$ pótśnie. Scherzo, inc. ${ }^{* *}[\mathrm{Na}$ modrem, na niebie...], Powrót wygnańca. Nokturn, inc. ${ }^{* *}$ [Gdzieś w śnieżnym, dalekim gdzieś świecie...]. Cykl zaś wieńczyły Echa niewoli. Impromtu, inc. *** [O, graj, jak szumi smętny gaj...]. Do kompozytora Oppman powrócił jeszcze w roku 1914, kiedy zamieścił w tomie Monologi utwór pochwalny na cześć Karola Ujejskiego i Chopina [Or-Ot 1914: 5-7]. Choć ta wdzięczność nie tylko Chopinowi, ale i romantycznemu poecie została wyrażona dopiero w roku 1914, to zależność Oppmana od Ujejskiego recenzenci dostrzegli po publikacji Wyboru poezji. Wydania nowego... w 1908 roku. Henryk Galle pisał wówczas, chwaląc utwory Oppmana, że poeta „nieraz kunsztowną zwrotką asnykowską olśniewa” [Galle 1908: 595]. Aby się o tym „dowodnie przekonać”, należy

wspomnieć cykl Szopenowskich pieśni, a zwłaszcza tak czysto, a donośnie brzmiące Srebrne dzwonki, albo falujące czarowną rytmiką walca Pożegnanie („Och, opleć mnie dłonią, och opleć mnie białą i główkę swą złotą na pierś mi złóż!") lub wreszcie preludia: Marzenie i Deszcz, najbardziej Ujejskiego thumaczenia Chopina przypominające [...]. [Galle 1908] 
W Pieśniach cykl poświęcony kompozytorowi inicjuje Pieśń Szopena, w której podmiot liryczny słucha muzyki mistrza, wygrywanej mu przez ukochaną. Nuty wybrzmiewające spod „białych rączek” anielskiego „dziewczęcia”, zwanego przez podmiot także „białym kwiatkiem”, mają niebywałą sprawczość. Oprócz tego, że wyzwalają w bohaterze zaprzepaszczony zapał „młodego serca”, budzą także wyobrażenie kompozytora. Oto:

$\mathrm{Z}$ pod błękitu płynie postać na welonach mgły, Smutny uśmiech ma na ustach, w oczach srebrne łzy.

Szopenowski duchu blady, w gwiazd koronie złotej, Widzę ciebie, władco tonów, śpiewaku tęsknoty! [Or-Ot 1894: 59]

We fragmencie tym Chopin przedstawiony jest w sztafażu na wskroś sentymentalnym, w tonach tęsknych i melancholijnych. Badacze zgodnie podkreślają, że do ukształtowania takiego wizerunku-legendy muzyka w XIX-wiecznej kulturze polskiej znacząco przyczynił się Stanisław Tarnowski. Nestor krakowskiej krytyki w wydanym w 1892 roku szkicu Chopin pisał:

Jakim był Chopin w swojej pierwszej młodości, jeszcze w Warszawie? Skłonnym do marzenia, do tęsknoty, do melancholii, nastrojonym z natury na minor, niezawodnie, ale nie rozstrojonym jeszcze, jak bywał w latach późniejszych. Była to tęsknota łagodna, jaką daje marzenie, nie ta ciężka i gorzka, jaką zostawia w duszy rzeczywistość i doświadczenie życia. Jedno z dzieł jego dawniejszych, dziewiąte z rzędu, nokturn (nr. 1.) jest odbiciem dość wiernym i charakterystycznem tego usposobienia i zarazem rodzaju jego talentu. [Tarnowski 1892: 14]

Historyk akcentował także podobieństwo muzyka do Juliusza Słowackiego („usposobieniem smutnym, nerwowym, chorobliwym” [Tarnowski 1892: 12]), wprost nazywał Chopina „człowiekiem nerwowym”, który pomimo tej ciążącej dolegliwości był na tyle „uprzejmy i miły, [...] że nawet gwałtowne antypatie, które jak wszyscy ludzi nerwowi miewał często i od pierwszego razu, nie 
brały góry nad wykwintną przyjemnością w obejściu” [Tarnowski 1892: 12]. Oppman w utworze inicjującym cykl poświęcony muzyce kompozytora wykorzystał zatem już wręcz obiegowe słowa na temat usposobienia polskiego mistrza. Jest ono ukonstytuowane tak, że wyobrażenie „władcy tonów” i „śpiewaka tęsknoty” nieodzownie splata się w nim z wrażeniami towarzyszącymi wsłuchiwaniu się w muzykę przez Chopina skomponowaną. Jego twórczość staje się wehikulem powrotu do tego, co utracone - wyzwala $\mathrm{z}$ rzeczywistości. Grana przez dziewczynę piosnka przeobraża się w pieśń - nokturn, płynie w „dal miesięczną, szybuje ku niebiosom, ma zdolność przenoszenia świadomości podmiotu lirycznego ku sferze niebiańskiej, wyżynom myśli i istnienia. Dlatego prosi on:

Graj mi jeszcze, dziewczę moje, graj mi jeszcze, graj!

Niech upaja moją duszę ten wrócony maj,

Ten wrócony maj miłości, wiary i zapału,

Co mnie drogą, kwieciem słaną, wiódł do ideału!...

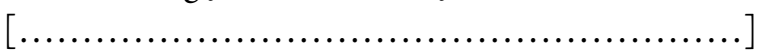

O, dzieweczko moja biała! u twych drobnych stóp,

$\mathrm{Z}$ prześnionemi marzeniami znów zawarlem ślub,

Chciałbym wiecznie tej piosenki słuchać, patrząc w ciebie,

Ciałem tutaj, sercem tutaj - ale duchem... w niebie...

[Or-Ot 1894: 6o]

Motyw wznoszenia się (nie tylko) pieśni, tak wyraźnie podkreślony w utworze inicjującym cykl, ma swoją reprezentację także w utworze następnym - Srebrne dzwonki. Kołysanka. Struktura sześciozgłoskowca, podzielonego na cztery równe strofy replikuje mnemotechniczny wzorzec piosenki i wymusza tym samym rytmiczność lektury Oppmanowskiego utworu. Powtarzającym się motywem, który w sposób klamrowy spaja wiersz, jest wspominany dźwięk dzwonka, wybrzmiewający z „wieżycy klasztornej”. Wers „Dzwoń dzwonku! dzwoń, srebrny” obecny w jest w strofie pierwszej dwa razy, przedzielony wersem „swój pacierz wieczorny”, a także w strofie czwartej - jako drugi i ostatni jej wers. Dla wyrazistego uwydatnienia kompozycyjnej klamry poeta zdecydował się na przetworzenie układu ze strofy pierwszej: „Dzwoń dzwonku! 
dzwoń, srebrny! / Swój pacierz wieczorny! / Dzwoń dzwonku! dzwoń, srebrny!”, której odpowiada następujący układ w strofie czwartej: „Swój pacierz wieczorny! / Dzwoń dzwonku! dzwoń, srebrny! / Swój pacierz wieczorny! / [...] / Dzwoń, dzwonku! dzwoń... dzwoń!” [Or-Ot 1894: 61-62]. Ostatni wers oddaje dźwięk cichnącego dzwonu, zamykając tym samym „akcję” całego liryku. Porządek dźwiękowy przekłada się na materiał poetycki nie tylko na poziomie onomatopei replikowanej $w$ wierszu, ale także w horyzontalnym układzie pozapoetyckiego odniesienia utworu. Dźwięk kościelnego dzwonu (bijącego być może na nieszpory lub kompletę) dociera do „strony podniebnej” (w strofie pierwszej), „chaty wieśniaczej” (w strofie drugiej), „cmentarnej ciszy” (strofa trzecia), by wrócić do „wieżycy klasztornej” - i umilknąć w cichnącym wersie wieńczącym wiersz. Charakterystyczna dla całego chopinowskiego cyklu Oppmana nie tyle muzyczność, ile dźwiękowość, wykorzystana do poetyckiego przełożenia i przetworzenia materiału muzycznego, przekłada się także na uwarunkowania przestrzenne w Kolysance. Dźwięk dzwonu pokonuje drogę między zakonną wieżą i ziemią, łącząc strefę ziemską z niebiańską. W „wieśniaczej chacie” modlące się dziecko „śle modlitwy” za „chmurnych tułaczy" - dusze czyśćcowe, a towarzyszem tych próśb, wyznaczającym ich czas oraz czas pracy, wiejskiego życia - jest właśnie dźwięk dzwonu. Jego odgłos docierający do cmentarza „kołysze zmarlych”, towarzysząc im w „błogim śnie”, będącym spoczynkiem tymczasowym - w nadziei na zmartwychwstanie. Bijące dzwony wydobywają z siebie „hymn czysty, jak łza”, będący „pacierzem wieczornym”. Struktura dźwiękowa wiersza oraz wertykalno-religijna współbrzmią ze sobą, tworząc dopełniające się i komentujące siebie nawzajem pola odniesienia, w których jednak w wymiarze kompozycyjnym prym wiodłaby charakterystyka dźwiękowa. Kołysanka stanowi świadectwo pełnego panowania poety zarówno nad materiałem poetyckim, jak i sferą wyobrażeniową - w pełni skorelowaną z sensem alegoryczno-symbolicznym liryku. Krąg inspiracji chopinowskich daje poecie nie tylko możliwość wyrażenia swoich fascynacji osobą kompozytora i jego dziełem, ale również zaprezentowania wokabularza oraz rejestru technik stylistycznych własnego warsztatu poetyckiego. Na przykładzie omawianego 
utworu zaobserwować można „przestrzenność” wyobraźni lirycznej Oppmana i jego zdolność do przekształcania zasobu środków językowych w wyobrażenia muzyczne i dźwiękowe.

Walc, kolejny utwór z cyklu, potwierdza tę charakterystykę. To dzieło nie tylko poety wieku nerwowego, piszącego liryk przy akompaniamencie dręczonej niepokojem wewnętrznym psychiki, ale również samego kompozytora, czy szerzej - wynik jego twórczości, poddanej upowszechnionej w epoce lekturze, podług której muzyka jest zarówno wyrazicielką wewnętrznych rozterek, jak i siłą je katalizującą. Wiersz jest ośmiostroficznym jedenastozgłoskowcem o regularnej budowie (strofa czterowersowa). Skomponowany został na podstawie układu klamrowego - na jego końcu występuje zreplikowana strofa pierwsza:

Och, opleć mnie dłonią, och, opleć białą!

I główkę swą złotą mi złóż!

Już stało się, dziewczę, co stać się miało -

Ostatni... ostatni nasz walc to już! [Or-Ot 1894: 64]

Zarówno w obrębie przywołanej strofy, jak i całego utworu rymy mają regularny (abab), choć niedokładny układ. Rymy niedokładne występują odpowiednio w strofie pierwszej, czwartej, szóstej i ósmej. Mimo że zadaniem niezwykle trudnym (jeśli nie daremnym) jest przypisywanie liryków Oppmana do konkretnych realizacji kompozycyjnych Chopina, można wysnuć hipotezę, iż omawiany liryk - być może - symuluje rytm jednego z najbardziej znanych walców kompozytora, mianowicie Walca cis-moll op. $64 \mathrm{nr}$ 2, napisanego w 1847 roku dla Charlotty de Rothschild. Bazujący na trzech tematach (tempo giusto, piú mosso oraz piú lento), o układzie abcbab utwór również posiada strukturę - jak na walc nietypową. Trzeci temat, wyraźnie wolniejszy od pierwszego, stanowi kontrast dla dwóch pozostałych, przełamując rytmikę utworu i wprowadzając w jego obręb elementy melancholijne. Być może intencją poety było powiązanie rytmiki poetyckiej wypowiedzi ze strukturą wspomnianego Walca. Wówczas strofy pierwsza i ostatnia stanowilyby komentarz do sytuacji lirycznej, skorelowanej z towarzyskim charakterem walca - okazją spotkania się kochanków przed 
ich rychłym rozstaniem. W takim przypadku strofy „klamrowe” nie byłyby elementem zasadniczej „akcji” wiersza, ale pełnilyby funkcję wiążącą przedmiot poetyckiej prezentacji ze sferą muzyczną i konkretną tejże realizacją. Tym samym niejako wyłączono by je z oddziaływania Chopinowskiej muzyki, stanowilyby do niej poetycki komentarz. Wówczas każdej strofie wiersza odpowiadałby jeden temat kompozycyjny z walca Chopina. Tę interpretację można udowodnić przy zastosowaniu analizy „nastroju” poszczególnych strof. Druga strofa wiersza, odpowiadająca w tak zarysowanej metodzie interpretacyjnej tematowi A (tempo giusto), koresponduje ze strofą szóstą i dzieli z nią sferę poetyckiego wyobrażenia. Wyrażone przez podmiot liryczny zdziwienie:

Jak dziwne, jak chmurne muzyki tony!

Ból wieje z nich taki, tchnie taka pleśń

Jak gdyby jęczały pogrzebne dzwony,

Jak gdyby płakała nadgrobna pieśń [Or-Ot 1894: 63]

koresponduje nie tylko z odpowiadającym mu, powolnym i dostojnym, tematem muzycznym, ale również ze strofą szóstą utworu:

I spycha mnie w otchłań, w przepaść nieznaną

Tej głębi, tej pustki lęka się wzrok!

Czy wejdzie tu słońce? Czy wzejdzie rano?

Czy wieczny w tym grobie panuje mrok? [Or-Ot 1894: 64]

Pogrzebne dzwony i ból, wspomniane w strofie drugiej, pojawią się ponownie w wymiarze lirycznej wyobraźni w strofie szóstej, gdy tańczący w rytm walca kochanek, opłakujący z wyprzedzeniem wkrótce utraconą miłość, doświadcza analogicznego nastroju duszy - zapowiedziana w strofie drugiej „nadgrobna pieśn” znajduje swoje dopełnienie w otchłani głębi i przepaści, przywołanych w ramach paralelnej strofy. Temat B (piú mosso) również zostaje odtworzony w konstrukcji wiersza Oppmana. Odpowiadałyby mu odpowiednio strofy: trzecia, piąta i siódma. Szybszy i bardziej wyrazisty temat drugi oddziałuje na treść wypowiedzi lirycznej. W strofie trzeciej czytamy: 
Zda mi się, że słyszę jęk jakiś głuchy,

Że pęka pierś czyjaś, zbryzgana krwią

Zda mi się, że wokól tańcują duchy,

Posępne, milczące, owiane mgłą. [Or-Ot 1894: 63]

W strofie piątej spotykamy zaś wspomnienie o „chmurnej muzyce”, która „mózg uśmierca” i „podstępnie się wkrada do mego serca”, a w strofie siódmej podmiot liryczny przywołuje „żałosne piersi twej drżenie". Łączność nie tylko wątków, ale też nerwowego klimatu, ewokowanego w obliczu prawdopodobnie dokonanej zbrodni, jest więc czytelna. Dodatkowo strofy te znacząco „uplastyczniają" - zarówno poprzez swoją niewątpliwą obrazowość, jak i konsekwencję operowania "grobowym” nastrojem - „akcję" liryku. Są elementem konsekwentnie konstruowanej przestrzeni konotowanej przez poszczególne fragmenty wiersza, odsyłające czytelnika w stronę ponurej, funeralnej makabreski. Treści stanowią tym samym rdzeń wypowiedzi poetyckiej, przesuwają jej sens w stronę kwestii zawartej w punkcie wyjściowym zwierzenia targanego smutkiem i rozpaczą serca stojącego w obliczu rozerwania więzi łączącej dwoje kochanków. W strofie czwartej, odpowiadającej najwolniejszemu tematowi C (piú lento), przełamującemu swym niespiesznym tempem strukturę utworu, ujawnia się wyznanie podmiotu lirycznego, rozciągającego dręczący go smutek na „świat szeroki”, w którym - podobnie jak w duszy podmiotu - jest „smutno i ciemno". Choć na poziomie obrazowym strofa ta nie jest najbardziej frenetyczna w całym utworze, to bez wątpienia sensy w niej zawarte mogą za takie zostać uznane. Podmiot konstatuje w wieńczącym strofę czwartą wersie, iż „szczęście, dziewczyno, [to - A.S.K., J.K.] przelotny ptak", co koresponduje - rzecz jasna z wymową całości liryku, ale jednocześnie stanowi kompozycyjny kontrapunkt sytuacji nadawczej, szczególnie skorelowanej z przywolanym w tytule motywem muzycznym.

Strofa czwarta powiązana jest znaczeniowo ze strofami pierwszą i ósmą, stanowiącymi klamry kompozycyjne wiersza. Poeta zastosował w nich deminutywy „główkę” oraz „dziewczę”, z których szczególnie ten drugi zasługuje na uwagę. W strofie czwartej podmiot zwraca się do swojej towarzyszki tańca, a zarazem 
(jeszcze przez czas jakiś) życia, używając słowa „dziewczyno” zrywa więc z czułą formą wypowiedzi w strofach „klamrowych”, co dobitniej podkreśla oddalenie od siebie dwojga kochanków, które następnie skonfrontowane zostało z konkluzją o trwałości szczęścia w ludzkim żywocie.

Walc Oppmana nie tylko w pewnym stopniu replikuje strukturę tematyczną kompozycji Chopina, ale także wchodzi z nią w artystyczny dialog. Towarzyski i wysublimowany charakter walca, przełamany przez kompozytora zarówno strukturą wewnętrzną, jak i melancholijnym brzmieniem, poeta przetwarza przy użyciu dostępnych mu środków poetyckich: skoncentrowanych na sferze frenetycznej oraz nerwowej. Obok konwencjonalnych obrazów duchów, tajemniczej mgły czy „piersi zbryzganej krwią”, stanowiących wokabularz nieszczęśliwej i - być może - zabronionej miłości, pojawiają się wyrażenia związane ze sferą nerwów. Jak wyznaje artysta: muzyka „mózg mój uśmierca”, powoduje więc nie tylko cierpienia duszy, ale także niemal cielesne katusze. Walc Opmanna jest więc walcem nerwowca, niewolnego od romantycznej sfery wyobrażeń. Podobnie jednak jak w przypadku Kołysanki poeta umiejętnie organizuje strukturę poetyckiej wypowiedzi i odnosi ją do odpowiednika muzycznego, aczkolwiek utwór Chopina zostaje w omawianym liryku zsubiektywizowany w sposób szczególny. Subiektywnie i autorsko Oppman potraktował strukturę tematyczną Walca cis-moll op. 64 nr 2 i przełożył ją na wewnętrzne uwarunkowanie części wiersza. Utwór zsubiektywizowany został także w treści: podmiot liryczny „chłonie” dźwięki walca, który kształtuje i formatuje jego odczucia oraz psychikę. Walc prezentuje nam wszak „nagą duszę” podmiotu - wystawioną na odczuwanie najmniejszych brzmień i taktów Chopinowskiej kompozycji.

W układzie Z motywów Szopena po Walcu następuje Mazurek. Utwór jest nieregularnym sześciozgłoskowcem, w którym sytuacja liryczna usytuowana została w dwóch przestrzeniach: w sferze życia wiejskiego, idyllicznej i przepełnionej autentyczną religijnością arkadii, oraz - świata wojennej pożogi, dokonującego wtargnięcia do sfery życia wiejskiego. Dla pełniejszego powiązania sfer świata przedstawionego poeta sięgnął po postaci na wskroś skonwencjonalizowane: sierotę, macochę i mężczyznę - Stacha, którego imię 
podane w deminutywnej formie wołacza „Stasieńku” przywołuje na myśl skojarzenia z Mickiewiczowską Romantycznością. Oppman zaprezentował również sferę nienachalnej erotyczności, komponującą się z witalistycznym obrazem „kwietnych pól”, do których wrócić miałby z wojny „Stasieniek”. Kobiecy podmiot liryczny którego imię pozostaje nieznane - jako nagrodę za powrót z teatru wojny obiecuje wręczyć swemu ukochanemu „różowy wianek”, gdyż - jak wyznaje - „cóż więcej nad to mam? Siebie mu dam...” [Or-Ot 1894: 66]. Wizja ta nie zostaje jednak urzeczywistniona w końcowej części wiersza widzimy Stasieńka, któremu „krwi z czoła cieknie zdrój”. Wiersz kończy się beznadziejnym okrzykiem: „O, Stachu mój!...” - nie tylko symbolicznie zamykającym akcję liryku, ale również ostatecznie zrywającym ze sferą witalistycznych wyobrażeń - wojna kończy życie Stacha i uczucie łączące dwoje kochanków, a zarazem burzy idylliczny obraz życia wiejskiego w sposób - rzec można - ostateczny. Przestrzeń wiejska oraz wojenna nie stanowią sfer oddzielonych od siebie jednoznacznie i wyraźnie, o czym świadczy konstrukcja samego wiersza czy też sposób przywoływania poszczególnych motywów. Groza wojny a co za tym idzie - zewnętrznego świata w sposób permanentny wisi nad idyllą. Autor zawarł ten fakt w zręcznej metaforze wyrażonej przez bohaterkę liryku w strofie pierwszej: „[...] za kwiatem schnie mi kwiat / Stasieńko poszedł w świat”. Z kolei w strofie trzeciej: „Poproszę Bożej matki / Niech wskrzesi moje kwiatki” poczyniona przez nią obietnica miłosnego spełnienia, zobrazowana florystyczną metaforą, nie może zostać zrealizowana - Stach najprawdopodobniej umiera od postrzału w głowę.

Choć Mazurek może zdawać się wierszem drobnym, czy nawet - również w obliczu innych chopinowskich liryków Oppmana - nieistotnym, to w sposób umiejętny operuje strukturą muzycznego wzorca. Na wskroś nowoczesne i wirtuozerskie brzmienie Chopinowskich mazurków dopełniane jest trójmiarowym taktem zaczerpniętym $\mathrm{z}$ tańców ludowych. W miejsce burdonów poeta zaproponował wizję wojny przetworzoną przez wrażliwość wiejskiej dziewczyny; świat wiejski jest tutaj sferą porywaną przez żywioł tego, co nowoczesne, współczesne - świat świstających kul, wojny i śmierci, niweczący krainę „kwietnych pól” 
i szczęścia kochanków, stanowi w wierszu Oppmana odwzorowanie sposobu realizowania przez mazurki Chopina motywów ludowych.

W następującym po Mazurku utworze Scherzo poeta nie pozostał wierny muzycznemu pierwowzorowi. Treść utworu nie jest żartobliwa, ale sentymentalno-żałobna - jakby wbrew tytułowi i formie muzycznej, z której artysta zaczerpnął wzorzec. Poeta opłakuje w pieśni utraconą miłość. Sytuacja liryczna zarysowana tuż pod koniec Scherza znajduje swoje dopełnienie w następującym po nim utworze $W$ btękitach. Podmiot liryczny wzlatuje wraz ze swym „białym aniołem” ponad ziemski padół przepełniony tęsknotami i łzami. Pieśń staje się środkiem eskapizmu, ucieczką od ziemskiej rzeczywistości, ludzkich zmartwień, jest wyrazem tęsknoty za rzeczywistością niebiańską i anielską. Oba liryki należy czytać jako konsekwentną kontynuację pewnej myśli, pełniej przełamującej żartobliwy i beztroski charakter scherza. Jako że są to utwory wieńczące cykl chopinowski w jego pierwotnej wersji, myśl ostatnia nie jest kontynuowana i brakuje jej finału. Zamyka ją wyznanie: „Na wietrze mknie z ziemi osnutej w kir / Żałobna pieśń luteń i lir...” [Oppman 1893: 70]. Oppman w pełni skonsolidował muzyczne i poetyckie środki wyrazu, podporządkowując je ewokowanej w utworach myśli nadrzędnej, postulującej potrzebę zapomnienia o sferze ziemskich trosk i uniesienia się w krainę od nich wolną. Modernistyczna symbioza sztuk osiągnęła więc swą - choć niedoskonałą - pełnię.

Analizując „lirykę chopinowską”, utwory Scherzo oraz $W$ błękitach należy interpretować w kontekście II sonaty fortepianowej b-moll, w której po części II Scherzo następuje część III Marche funèbre: Lento. W wyniku dążeń poety do formalnego, strukturalnego odwzorowania Chopinowskiej sonaty ucierpiała czytelność struktury poetyckiej i uwarunkowań wewnętrznych całego cyklu. Zbiór Z motywów Szopena nie byłby - co oczywiste - odwzorowaniem II sonaty fortepianowej - jednak wyraźna jest w nim inspiracja Chopinowską kompozycją jako wzorcem dla zamknięcia cyklu: wiersz Scherzo odpowiadałby scherzo w układzie sonaty kompozytora. Utwór $W$ błękitach stanowi zaś poetycką wariację nad Marche funèbre: Lento. Wieńcząca sonatę część IV Finale nie miałaby swojego „odpowiednika” poetyckiego - Oppman, być 
może, stwierdził, iż relacja treściowa zachodząca między wierszami Scherzo i $W$ blękitach w stopniu wystarczającym wskazuje na powinowactwo jego poezji z dziełem Chopina, a może nie znalazł odpowiedniego formalnie utworu, który mógłby wejść w interakcję z ostatnią częścią sonaty.

W wydanym w 1908 roku Wyborze poezji poeta zrezygnował z umieszczenia po Scherzo utworu $W$ btękitach. Tym razem następowały po nim Powrót wygnańca. Nokturn oraz Echa niewoli. Impromptu. Pierwszy z przywołanych liryków do wspomnianego w jego tytule nokturnu podchodzi na wskroś poetycko, skupiając się na zarysowaniu „krajobrazu wewnętrznego” bohatera wiersza. Dziewięciozgłoskowy, czterostrofowy (osiem wersów przypadających na strofę) liryk przybliża historię wygnańca, który powróciwszy najpewniej ze „śnieżnego dalekiego świata” Syberii, „ukląkł pod krzyżem, jak dziecię" i opłakuje zmarłą podczas jego nieobecności rodzinę. Sytuacja absolutnej rozpaczy bohatera liryku dopełniona została obrazem niebios ginących we mgle toni. Oppman, by uwydatnić moment - rzec można - graniczny dla byłego zesłańca, posłużył się więc motywem „szarej godziny” jako strefy przejścia między radością z powrotu do „ziemi macierzy” i przeżywaną na świeżo stratą najbliższych, których od śmierci nie uchroniły nawet słane z syberyjskiej turmy „modlitwy i pacierze”. Szara godzina niechybnie przejdzie w noc - tak jak ludzkie życie nieubłaganie wieńczy „mogiła” Tym razem poeta nie odwzorowuje układu któregokolwiek z Chopinowskich nokturnów - zależy mu na wyeksplikowaniu nastroju grozy i melancholii formy muzycznej oraz przełożeniu tychże na sferę duchową bohatera liryku, a nie jak miało to miejsce w cyklu $Z$ motywów Szopena - na strukturę językową utworu.

Powrót wygnańca. Nokturn w pełni wpisuje się w sferę Chopinowskich inspiracji, ale kładzie większy nacisk na psychologiczny wydźwięk całości. Zmienia się zatem pole oddziaływania muzyki kompozytora - ze sfery językowej oraz konstrukcyjnej lub wewnątrzpoetyckiej dotyka ona najpełniej bohatera utworu. Istotnie, czytamy niemal na bieżąco zdawaną relację z zapadania w psychice wygnańca „nocy duszy”. Poeta uzyskał ten efekt poprzez zastosowanie techniki znanej nam już z Kołysanki: dźwięk dzwonka 
stanowi istotne dopełnienie akcji liryku oraz komentarz do niego, sięga poza sferę dźwiękowości, wpływając na konstrukcję sensu utworu. Czy przywołany w Powrocie wygnańca „dzwonek na wieży” jest tym samym, którego dźwięki wypełniają przestrzeń dźwiękową Kołysanki, dociec nie sposób. Ważniejsza zresztą od prostych przeniesień przedmiotowych jest w interesującym nas tutaj przypadku analogiczność techniki poetyckiej oraz cel jej zastosowania.

Dzwonki wchodzą z bohaterem w dialog, odpowiadając na rzucane przez niego (być może podług ich zamysłu w momencie wypowiedzenia) retoryczne pytania. Na kwestię: „gdzie moi najmilsi?” - dzwonki odpowiadają: „w mogile”; na stwierdzenie:

Ach, jednak zostały mi jeszcze

Te nasze, te łąki i niwy.

W nich hufce skrzydlatych rycerzy

Śpią, krwawe złożywszy pałasze [Oppman 1908: 41]

dzwonki odpowiadają: „nie nasze... nie nasze... nie nasze...”. Na pytanie: „któż smutek, któż ból mój uśmierzy” - dzwonki ripostują natomiast: „sen śmierci... sen śmierci... sen śmierci...” [Oppman 1908: 41]. Interesująca jest obrana przez Oppmana strategia dekonstrukcji sensów życia wygnańca. Dostrzec w niej można jawną strukturę degradacyjną: pierwsze pytanie dotyczy słońca, które zdaniem bohatera - winno górować nad ziemią ojczystą; drugie rodziny; trzecie - sfery narodowej i patriotycznej, ale obejmującej mogiły powstańców - ze sfery podniebnej schodzimy więc niżej i niżej, by przylgnąć z wygnańcem do ziemi, powaleni przez ciężar „nocy duszy”. Omówiony wiersz stanowi, jeśli nie najdoskonalszy poetycko, to z pewnością jeden z ciekawszych Chopinowskich liryków Oppmana, z wyrazistością i umiejętnością oddający stan psychiki bohatera. Liryk dobrze eksploruje również nastrój przywołanego w tytule motywu muzycznego, dzięki czemu nie jest on lichym przyczynkiem do konstrukcji wypowiedzi poetyckiej, ale niebanalnym doń komentarzem i dopełnieniem.

Podobna zależność między muzyką i przedmiotem wypowiedzi poetyckiej zachodzi w liryku Echa niewoli. Impromptu. Oppman znowuż przywołuje formę muzyczną w celu zaimplementowania 
w przestrzeń liryku ewokowanego przez muzykę nastroju - jego ambicją nie jest już replikowanie struktur kompozycyjnych. Wiersz nie odwzorowuje trójdzielnego układu impromptu, gdyż składa się z czterech strof po osiem wersów o nieregularnej wersyfikacji. Każda strofa rozpoczyna się apelem: „O, graj!”, skierowanym - być może - do samego Chopina, by ów w swym zaświatowym bycie w zaimprowizowanym utworze fortepianowym dał wyraz męce niewoli, przywoływanej w sugestywnych obrazach, m.in. "Jak stroi kwietny maj / Te krzyże na mogile" [Oppman 1908: 42-43]. Bez wątpienia poeta wprowadził w przestrzeń wiersza symetryczną strukturę Chopinowskiego impromptu, ale potraktowaną tutaj jako pole do wyrażenia szarganej bólem duszy podmiotu lirycznego.

Struktura wiersza jest gradacyjna - żal i tęsknota podmiotu potęgują się ze strofy na strofę. W pierwszych trzech obowiązuje układ symetryczny - powtórzone są kolejno wersy pierwszy i trzeci oraz piąty i siódmy, tworzą więc pary okalające położone pomiędzy nimi wersy. I tak dla przykładu strofa druga została skomponowana w sposób następujący:

O, graj!

Jak płynąc w niebios kraj, Anioły w gwiazd diademie Jak płynąc w niebios kraj, Żegnają chmurną ziemię, Jak z naszych smętnych chat Najkrwawsze skargi niosą Jak z naszych smętnych chat Do Boga niosą łzy... [Oppman 1908: 42-32]

W ostatniej strofie dochodzi jednak do załamania tej symetrii. Być może pod ciężarem wypełniającego duszę żalu, być może aby oddać wygasanie improwizowanego utworu, poeta zdecydował się na następujące przekształcenie tego fragmentu:

O, graj!

Jak zniknął cudny raj,

Jak brzmią pogrzebne dzwony, 
Jak zniknął cudny raj

Do dzisiaj nie wrócony,

Jak krwawo tęsknisz ty:

Do czego?... po kim?... za czem?...

Jak krwawo tęsknisz ty...

Jak krwawo tęsknię ja... [Oppman 1908: 42-43]

Zakończenie utworu, jego ostatni wers, ma wymowę szczególną. Oto uderzający po raz ostatni w klawiaturę - być może - sam Chopin dotyka podmiotu mówiącego - wiele wskazuje, iż samego poety. Forma impromptu, choć nie została odwzorowana w strukturze wiersza, z pewnością uobecnia się poprzez siłę wyrazu, żywiołowości i porywczości szczerego oddania tęsknoty i niepewności. Wieńczący cykl utwór nie tyle replikuje strukturę kompozycyjną, ile skupia się na wymiarze uczuciowym. Takie potraktowanie źródłowego materiału muzycznego umożliwia więc - podobnie jak w wierszu Powrót wygnańca. Nokturn - przywołanie ewokowanych przez niego uczuć, choć - co należy zaznaczyć - sfera ich oddziaływania jest odmienna niż we wcześniejszej realizacji cyklu $Z$ motywów Szopena. Wówczas przesłanki patriotyczne były zupełnie nieobecne, poeta skupiał się na wyrażeniu indywidualnych odczuć, cierpienia zsubiektywizowanej duszy - muzyka drażniła jego nerwy, a serce doprowadzała do, by się tak wyrazić, ekstatycznej rozpaczy. W przypadku dwóch przywołanych liryków należy mówić o rozszerzeniu przestrzeni oddziaływania muzyki. Zarówno Powrót wygnańca, jak i Echa niewoli służą do zobrazowania sytuacji bardziej powszechnej, gdyż odnoszącej się do całej społeczności, i choć w celu zobrazowania tejże sięgają do uczuć zindywidualizowanych, to bez wątpienia wydźwięk utworów jest wspólnotowy. Tym, z czego poeta jednak nie zrezygnowal, jest połączenie za sprawą Chopinowskich kompozycji sfery nieba i ziemi. W historii wygnańca i w zaimprowizowanej skardze na niewolę - muzyczność czy też dźwiękowość wiersza służą zbudowaniu pomostu między sferą ziemskich odczuć i górującą nad nią sferą odniesienia. Nieprzypadkowo tułacz po powrocie w rodzinne strony zastanawia się nad przyczyną obecności słońca na niebie, a w Echach niewoli poeta przywołał liczne obrazy związane ze sferą niebiańską. Warto 
jeszcze podkreślić, że Szopenowskie pieśni z tomiku z 1908 roku inicjował utwór Szopen, nieobecny we wcześniejszych realizacjach. W tej najnowszej edycji cykl poświęcony kompozytorowi bodaj w sposób najbardziej wyraźny uzyskał patriotyczną osnowę. Muzyk przedstawiony jest jako ten, który „Przylgnął [...] do ziemi, posłyszał jej łkanie" [Oppman 1908: 25]. Podmiot liryczny wskazuje źródła Chopinowskiej twórczości, które są nierozwiązalnie związane z historią Polski. Jej dawno utraconą świetność symbolizują „zwycięskie rapsody skrzydlatej husarii” przeciwstawione współczesnym „smutnym pacierzom wygnańców na stepach Sybiru” [Oppman 1908: 25]. Polski lud określony jest mianem „skazańców”, zaś Chopin zwany jest ich poetą. To jemu Bóg przepowiada, że Polska „wstanie”. W tej dobie widzenia kompozytor urósł na „serc monarchę i króla tonów" [Oppman 1908: 26], po czym zaklął pieśń „by nam grała, jak się groby kwiecą / I budząc nas, i łudząc echem dawnej chwały...” [Oppman 1908: 26].

Opisane parabole muzyczno-poetyckie wskazują na pewną istotną cechę Oppmanowskiej propozycji fabularyzacji utworów Chopina. Nie dąży poeta jedynie do odwzorowania w swej rytmice i porządku stroficznym kompozycji muzyka, ale szuka również powinowactwa treściowego i stara się dokonać translacji materiału muzycznego na język poezji w wymiarze relacji kompozycyjnych i organizacyjnych. Wizja twórczości kompozytora, która wyłania się z cyklu $Z$ motywów Szopena, jest wszechogarniająca nie tylko na poziomie afektywno-uczuciowym czy impresyjnym, ale również strukturalnym utworów. Pytaniem otwartym pozostaje, czy wskutek zestawienia dwóch - nie do końca ze sobą skorelowanych - porządków organizacyjnych osiągnięto pełną czytelność literackiego przesłania. Tkwi w nim jednak spory potencjał - pieśni unoszącej się ku niebiosom. 


\section{Bibliografia}

Drogoszewski Aureli (1900), Literatura polska. Or-Ot (Artur Oppman), „Prawda”, nr 45, s. 540-541.

Galle Henryk (1908), Artur Oppman (Or-Ot). Wybór poezji. Wydanie nowe, zmienione i powiększone, z portretem autora. Warszawa nakład Gebethnera i Wolffa, Kraków. G. Gebethner i Sp. 1908, 12-o, str. 299, „Biblioteka Warszawska”, t. 4, s. 595-596.

Hejmej Andrzej (2020), Chopin w literaturze, [dostęp: 20 lutego 2020], https://tinyurl.com/foukbw79.

Kozłowski Stanisław (1893), Or-Ot (Artur Oppman), „Pieśni”, „Gazeta Polska”, nr 274, s. 3 .

Oppman Artur (1898), Z motywów Chopina, „Życie”, nr 40/41, s. 521. Oppman Artur (Or-Ot) (1908), Wybór poezji. Wydanie nowe, zmienione i powiększone, Gebethner i Wolff, Warszawa-Kraków.

Or-Ot [właśc. Artur Oppman] (1890), Preludium, inc. ${ }^{* *}$ [Szopenowska piosnka płynie...], „Echo Muzyczne, Teatralne i Artystyczne”, nr 340, s. 162.

Or-Ot [właśc. Artur Oppman] (1892), Walc, „Myśl”, nr 22, s. 187.

Or-Ot [właśc. Artur Oppman] (1894), Pieśni, Paprocki i Spółka, Warszawa.

Or-Ot [właśc. Artur Oppman] (1900), Wybór poezji, Gebethner i Wolff, Warszawa.

Or-Ot [właśc. Artur Oppman] (1914), Monologi, Gebethner i Wolff, Warszawa.

Tarnowski Stanisław (1892), Chopin i Grottger. Dwa szkice, Księgarnia Spółki Wydawniczej Polskiej, Kraków.

Aleksandra Sikorska-Krystek, Jędrzej Krystek

\section{A Song for the Heavens. Echoes of Chopin in Artur Oppman's Works} This article presents a cycle of lyrical works entitled $Z$ motywów Chopina (From Chopin's themes) by Artur Oppman, published in 1893 in the volume Pieśni (Songs). The shape of this cycle had been modified over the years. In 1908, the poet changed its title and expanded it with new works. This change testifies to the evolution of the creative concept and the set of ideas about the function of the composer's work. Contrary to the opinion rooted in the tradition of research about the conventional approach to the impact of Chopin's work presented in Oppman's lyrical poetry, the authors of the article demonstrate a far-reaching originality of the discussed work, focusing their attention both on issues related to understanding the narrowly-defined poetological knowledge and on the problem of translating musical means of expression into the language of a literary work. 
Keywords: Artur Oppman; Frédéric Chopin; poetry; correspondence of arts; modernism.

Aleksandra Sikorska-Krystek - absolwentka filologii polskiej na Uniwersytecie im. Adama Mickiewicza w Poznaniu, doktorantka w Zakładzie Literatury Romantyzmu na Wydziale Filologii Polskiej i Klasycznej Uniwersytetu im. Adama Mickiewicza w Poznaniu i na Uniwersytecie we Fryburgu. Autorka artykułów publikowanych w „Pamiętniku Literackim”. Przygotowuje pracę doktorską w ramach projektu Spotem! / Ensemble! : L'interrelation entre la littérature et les sciences sociales en Pologne autour de 1900 et ses répercussions poświęconą wyobraźni społecznej Marii Konopnickiej. Dokumentalista i norwidolog.

Jędrzej Krystek - doktorant w Zakładzie Literatury Romantyzmu na Wydziale Filologii Polskiej i Klasycznej Uniwersytetu im. Adama Mickiewicza w Poznaniu. Laureat Konkursu Stypendialnego Fundacji im. Anneliese i Mieczysława Koćwin na rok 2020-2021. Autor artykułów publikowanych w „Pamiętniku Literackim”, „Poznańskich Studiach Polonistycznych. Serii Literackiej”, „Czasie Kultury”. Przygotowuje pracą doktorską na temat sprawy Makryny Mieczysławskiej. Interesuje się dziejami europejskiego nihilizmu i mistyką Juliusza Słowackiego. Dokumentalista, miłośnik twórczości Fiodora Dostojewskiego, Ernsta Jüngera i Wiesława Myśliwskiego. Od niedawna zafascynowany czytelnik litewskiej prozy. 